\title{
A new species of Omphale Haliday 1833 (Hymenoptera: Eulophidae) from Brazil, parasitic on gall-midges on Croton floribundus Spreng (Euphorbiaceae)
}

\author{
Gabriela Cristina Gomes ${ }^{1}$, Maíce Siqueira Franco ${ }^{1}$ \& Christer Hansson ${ }^{2,3}$ \\ ${ }^{1}$ Departamento de Biologia Animal, Instituto de Biologia, \\ Universidade Estadual de Campinas - UNICAMP, CP 6190, CEP 13083-970, Campinas, SP, Brasil \\ ${ }^{2}$ Scientific Associate of the Entomology Department, the Natural History Museum, \\ Cromwell Road, London SW7 5BD, United Kingdom \\ ${ }^{3}$ Corresponding author: Christer Hansson,e-mail: christerdennis@gmail.com
}

GOMES, G.C.; FRANCO, M.S. \& HANSSON, C. A new species of Omphale Haliday 1833 (Hymenoptera: Eulophidae) from Brazil, parasitic on gall-midges on Croton floribundus Spreng (Euphorbiaceae). Biota Neotrop.13(3): http://www.biotaneotropica.org.br/v13n3/en/abstract?article+bn00713032013

Abstract: A tritrophic relationship involving the plant Croton floribundus Spreng (Euphorbiaceae), an unidentified gall-midge belonging to either Clinodiplosis Kieffer 1895 or Alycaulus Rübsaamen 1916 (Diptera: Cecidomyiidae), and a new species of parasitic wasp belonging to Omphale Haliday 1833 (Hymenoptera: Eulophidae) is described. The gall and Omphale japii sp. nov., are described and illustrated. This is the third record of Omphale from Brazil and the new species is compared to other Omphale species from the Neotropical region.

Keywords: gall-maker, Cecidomyiidae, parasitoid, tritrophic interaction, Neotropical.

GOMES, G.C.; FRANCO, M.S. \& HANSSON, C. Uma nova espécie de Omphale Haliday 1833 (Hymenoptera: Eulophidae) do Brasil, parasitoide de galhas em Croton floribundus Spreng (Euphorbiaceae). Biota Neotrop. 13(3): http://www.biotaneotropica.org.br/v13n3/pt/abstract?article+bn00713032013

Resumo: Neste estudo foi descrita a relação tritrófica envolvendo a planta Croton floribundus Spreng (Euphorbiaceae), um galhador não-identificado pertencente à Clinodiplosis Kieffer 1895 ou Alycaulus Rübsaamen 1916 (Diptera: Cecidomyiidae), e uma nova espécie de vespa parasitoide pertencente à Omphale Haliday 1833 (Hymenoptera: Eulophidae). A galha e Omphale japii sp. nov., foram descritas e ilustradas. Este é o terceiro registro de Omphale no Brasil e a nova espécie foi comparada a outras espécies de Omphale da região Neotropical. Palavras-chave: galhador, Cecidomyiidae, micro-himenóptero, interação tritrófica, Neotropical. 


\section{Introduction}

There are several regulatory processes in population dynamics. Tritrophic interactions between plants, herbivores, and their natural enemies is one of these, known as "bottom-up" (plants defense) or "top-down" (through natural enemies) processes (Price et al. 1980). Parasitoid insects, especially Hymenoptera parasitoids, are important natural enemies (Hanson \& Gauld 2006). A tritrophic interaction involving Croton floribundus Spreng (Euphorbiaceae), Cecidomyiidae (Diptera) gall-makers, and a parasitoid belonging to Omphale Haliday 1833 (Hymenoptera: Eulophidae) attacking the gall-makers, is reported in this paper.

The plant in the tritrophic relationship, Croton floribundus (Euphorbiaceae), is a tree up to 13 meters high and is native to Brazil where it is known as "capixingui" or "tapixingui". This tree requires ample light conditions and grows typically along forest edges, roads or paths in forests. Due to these light requirements it is a pioneer species characteristic of secondary semideciduous forests and is valuable for, and widely used in, reforestation programs (Fernandes et al. 2010). It also has medicinal properties including anti-inflammatory features (Correa 1984), and also with a potential to curb schistosomiasis (Medina et al. 2009).

Omphale Haliday 1833 is one of the largest genera in the subfamily Entedoninae, including 259 species worldwide (Noyes 2012). The knowledge of Omphale is concentrated mainly to Europe (Graham 1959, 1963; Bouček \& Askew 1968), North America (Hansson 1996, 1997) and Central America (Hansson 2004). In the study of the fauna of Central America, which included 129 Omphale species - the majority of which were described in the study, the focus was on Costa Rica. Thus it has been shown that Omphale is well represented in the Neotropical region. However, the knowledge of the group in South America is very poor. In his catalogue on the Chalcidoidea of the Americas south of the U.S. De Santis (1979) listed only one species under Omphale, O. striata Howard 1897. It had been described from the island of Grenada, i.e. not from the South American mainland, and it has later been transferred from Omphale to Euderus (LaSalle \& Schauff 1992). Hansson (2004) added a few species for South America and two of these, O. divina (Girault 1916) and O. insetosa Hansson 2004, were recorded from Brazil. The new species described here is thus the third species of Omphale known from Brazil.

Omphale species develop as koinobiont primary endoparasitoids (Dziurzynski 1961) and their hosts are gall-makers, mainly gallmidges (Diptera: Cecidomyiidae) (Bouček \& Askew 1968, Hansson 1996, 2004). However, the hosts and biology are known only for a minority of species. For instance, in the Costa Rican study (Hansson 2004) hosts were recorded for only ten of the 129 species. The biology is an important part of species information and the new species described here has been reared from a host and the information published here is therefore a valuable contribution to the knowledge of this group.

\section{Material and Methods}

This study was carried out at Serra do Japi Reserve, Jundiaí, SP, Brazil, in February and March 2011. Leaves with galls were collected and the leaves were kept separate in petri dishes pending the emergence of adults of gall-makers and parasitoids. The reared specimens were killed and kept in $80 \%$ ethanol. The alcohol preserved specimens were subsequently dried using a critical point drier and mounted on a rectangular card as described by Noyes (1982).

The SEM photos were made from uncoated specimens on their original cardboard mounting. This was possible to do in low vacuum mode on a JEOL® JSM 5600LV SEM microscope. The colour photos were taken through a Nikon SMZ 1000 microscope with Nikon camera equipment DS-L1 \& DS-5M. Each photo was made by merging several photos taken at different focus levels using the software Helicon Focus ${ }^{\circledR}$ Pro version 4.75.

The terminology used here follows Gibson (1997). For illustrations of the morphological terms see www.neotropicaleulophidae.com.

Acronyms of museums where material is deposited: BMNH (the Natural History Museum, London, UK), MUNI (Museum of Unicamp, Campinas, SP, Brazil), MZSP (Museu de Zoologia da Universidade de São Paulo, Brazil).

\section{Descriptions}

\section{The gall (Figures 2-4)}

The gall is always situated on the upper surface of the leaf (Figures 2, 4). It is a "furry" gall covered in long filaments (Figure 3). As young it is shaped like a ball, but as mature it is more or less ovoid - always higher than wide. The semi-minor axis of the gall is 1-7 $\mathrm{mm}$ with a mean of $2.5 \mathrm{~mm}$, and semi-major axis $1-7 \mathrm{~mm}$ with a mean of $3.2 \mathrm{~mm}(\mathrm{n}=189)$. The number of galls per leaf varied from 1 to 38 with a mean of 6.7 galls/leaf $(n=367)$. The location of the galls on the leaf was with $70.5 \%$ in basal third, $28.5 \%$ in middle third and $1.0 \%$ in distal third $(\mathrm{n}=189)$. The gall-inducer is a gall-midge (Diptera: Cecidomyiidae) belonging either to Clinodiplosis Kieffer 1895 or Alycaulus Rübsaamen 1916 (Maria Virgínia Urso-Guimarães, personal information).

This gall is similar to the gall on Croton floribundus found at Serra de São José, Minas Gerais, Brazil by Maia \& Fernandes (2004). Both galls are ovoid leaf-galls that are slightly hairy. They are possibly galls induced by the same gall-midge but it is difficult to tell because Maia and Fernandes did not identify the gall, nor did they mention any insects reared from it.

\section{The parasitoid}

Omphale japii sp. nov. (Figures 1, 5-18)

Diagnosis. Clypeus with rounded sides (Figure 11), i.e. not quadratic in shape; petiole dorsally with a laminar projection (Figure 18). Similar to O. flavirufa Hansson 2004, and runs to that species in the key to Costa Rican Omphale-species Hansson (2004), but differs from $O$. flavirufa in having occipital margin rounded (Figure 15), female with mesoscutum completely metallic (Figure 7), forewing with an infuscate spot below the stigmal vein (Figure 9), with radial cell bare (Figure 9), and with postmarginal vein longer, 1.5-1.8X as long as stigmal vein.

\section{Description. Female. Length of body 1.7-1.9 mm.}

Scape yellowish-brown with dorsal edge dark brown, pedicel and flagellum dark brown (Figure 5). Frons below frontal suture black with metallic green and golden tinges, above frontal suture golden, clypeus black with golden tinges (Figure 6). Vertex golden-purple. Mesoscutum with posterior $1 / 2$ golden-purple and with anterior $1 / 2$ golden-green, to completely golden-green (Figure 7). Scutellum golden-purple with posterior $1 / 5$ dull golden-green, to completely golden-green (Figure 7). Dorsellum black with golden-green tinges (Figure 7). Propodeum black to dark brown with golden tinges (Figure 7). Fore coxa dark brown, mid coxa pale brown with base dark brown to completely dark brown, hind coxa yellowish-brown; femora pale brown; tibiae and tarsi yellowish-brown, $4^{\text {th }}$ tarsomere dark brown (Figure 1). Wings hyaline, forewing with an infuscate spot below stigmal vein (Figure 9); wing interference patterns as in Figure 8. Petiole yellowish-brown (Figure 7). Gaster black, first 


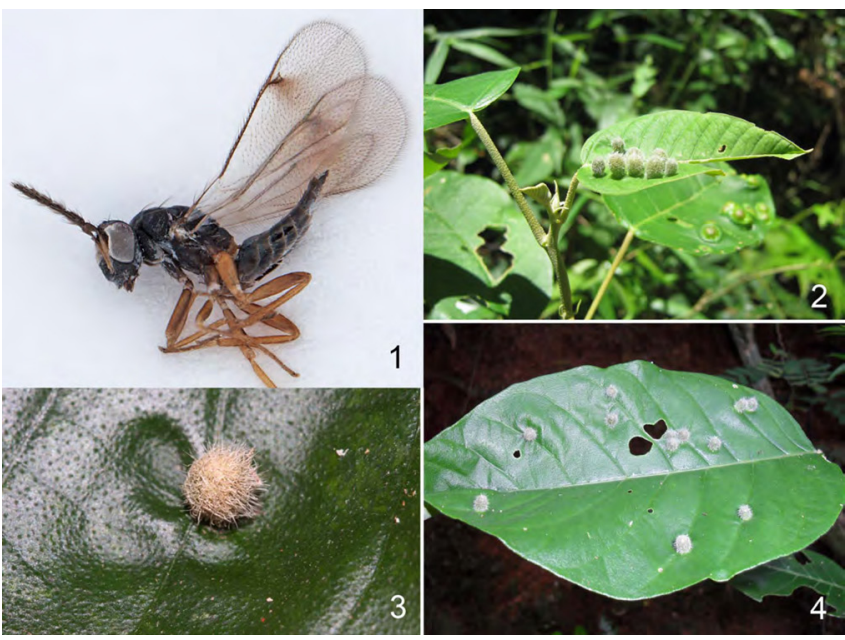

Figures 1-4. 1. Omphale japii sp.nov., habitus in lateral view, female, length of body $1.8 \mathrm{~mm}$. 2-4. Galls of Clinodiplosis/Alycaulus sp. (Diptera: Cecidomyiidae) on Croton floribundus. 2. Galls on a tender leaf. 3. Close-up of a gall. 4. Galls on a mature leaf.
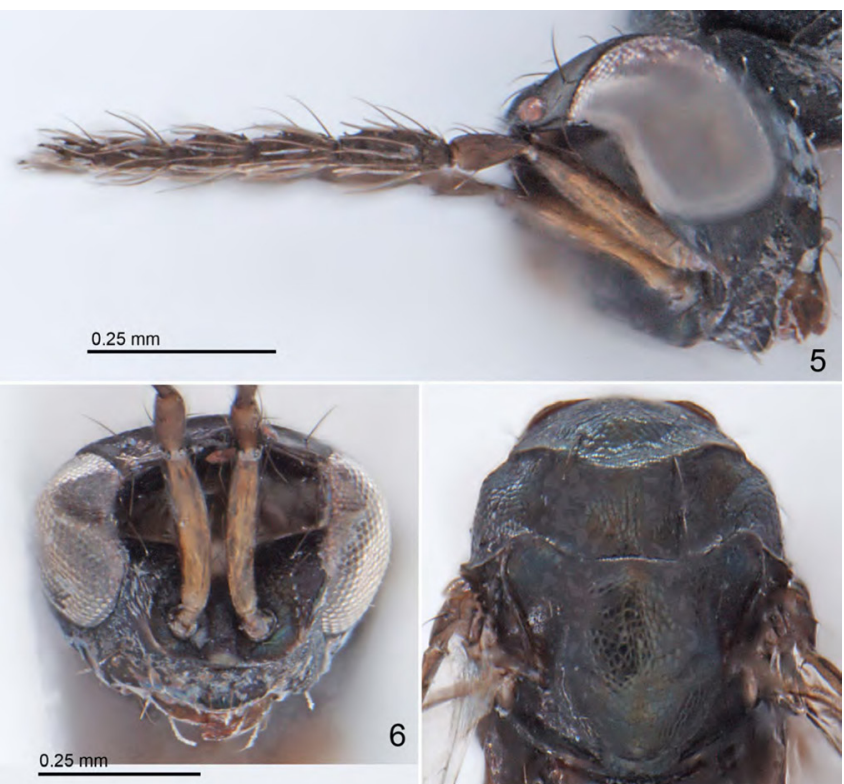

6
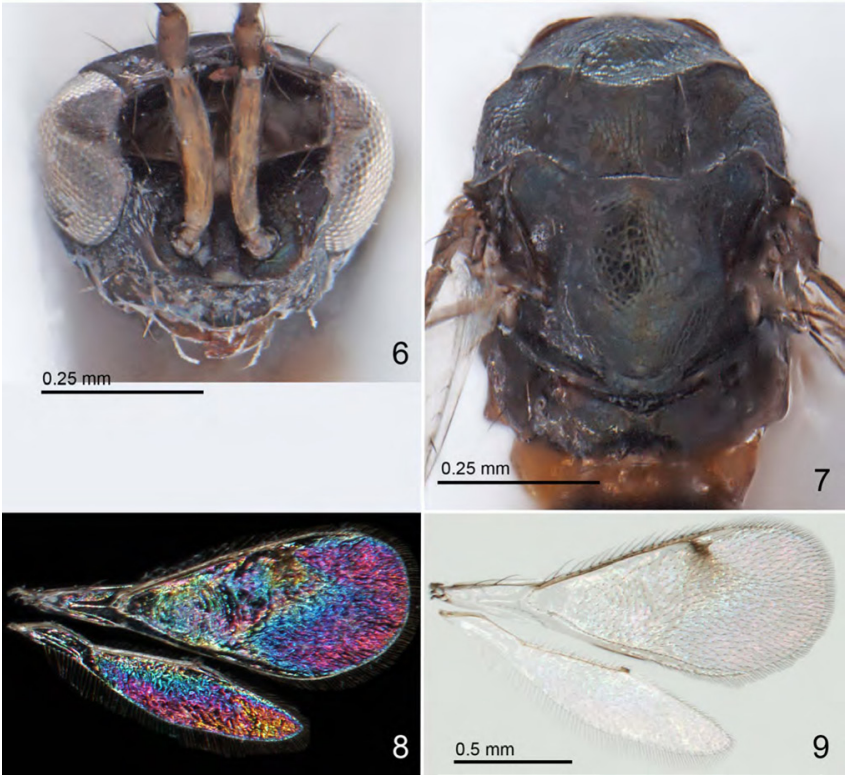

Figures 5-9. Omphale japii sp.nov., female. 5. Head with antenna in lateral view. 6. Head in frontal view. 7. Mesosoma in dorsal view. 8. Right wing-pair with interference pattern. 9. Right wing-pair in transparent mode.

tergite with golden-green and golden tinges, remaining tergites with golden tinges.

Antenna as in Figures 5, 14; flagellum with two short discoid anelli (Figure 12); sensilla ampullacea short and asymmetric (Figure 13). Vertex smooth (Figure 15). Frons with a frontal crossridge and with frontal suture V-shaped (Figure 10); below frontal

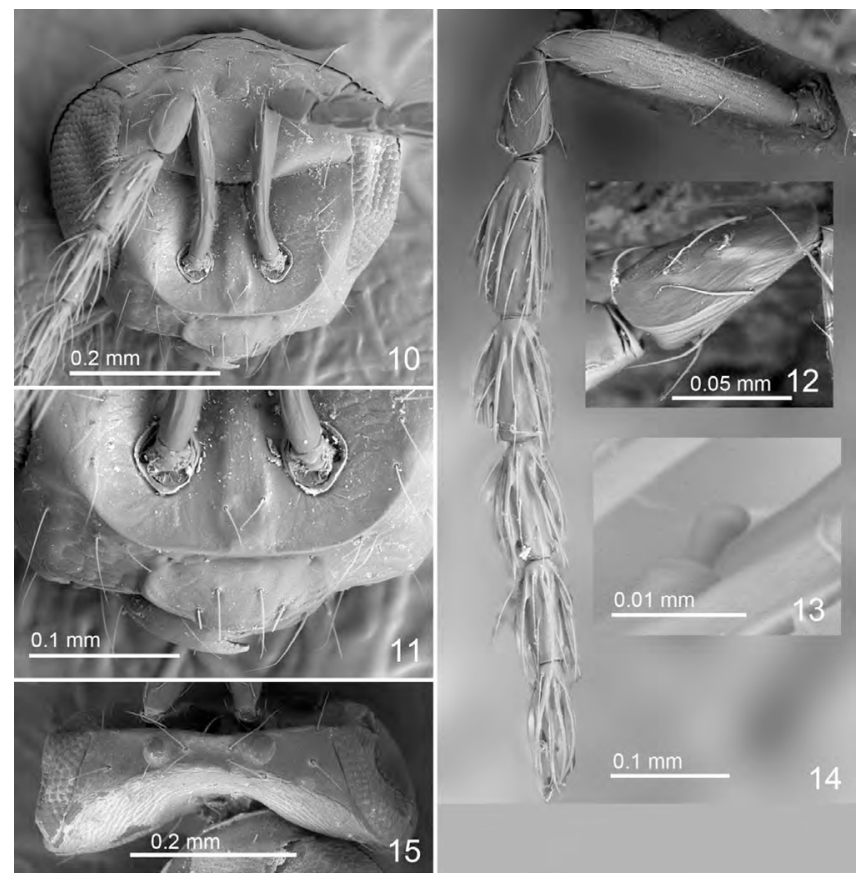

Figures 10-15. Omphale japii sp.nov., female. 10. Head in frontal view. 11. Lower part of head in frontal view with clypeus. 12. Part of antenna in lateral view with pedicel and two discoid anelli. 13. Sensillum ampullacea on flagellomere in lateral view. 14. Antenna in lateral view.

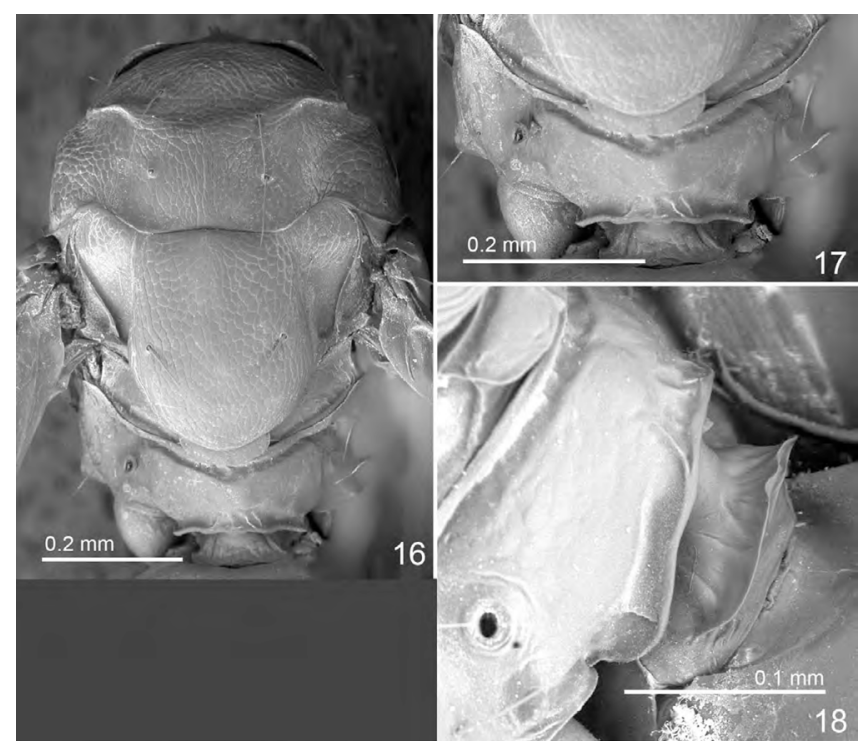

Figures 16-18. Omphale japii sp.nov., female. 16. Mesosoma in dorsal view. 17. Propodeum in dorsal view. 18. Petiole in lateral view.

suture with weak engraved reticulation, smooth close to eyes and close to frontal cross-ridge; above frontal suture smooth. Clypeus with very weak reticulation, rounded sides, roundly protruding lower margin, and 2.6X as wide as long (Figure 11). Occipital margin rounded (Figure 15). Ratios of height of eye/malar space/width of mouth 3.1/1.0/3.3; distance between posterior ocelli/posterior ocellus and compound eye/posterior ocelli and occipital margin 10.3/7.0/1.0; width of head/with of thorax 1.2.

Mesoscutum and scutellum with strong and engraved reticulation (Figure 16); midlobe of mesoscutum with two pairs of setae and 
scutellum with one pair. Dorsellum flat and smooth (Figure 17). Forewing speculum closed below (Figure 9); with 7-11 admarginal setae attached to ventral surface of marginal vein, without stigmal hairlines but with radial cell bare. Propodeum smooth and shiny with a groove along anterior margin (Figure 17); propodeal callus with 2 setae; petiolar foramen rounded triangular. Ratios of length of wing/length of marginal vein/height of wing 1.8/1.1/1.0; length of postmarginal vein/length of stigmal vein 1.5-1.8.

Petiole short and wide, dorsally with a laminar projection (Figure 18). Gaster ovate-elongate; last tergite $0.6 \mathrm{X}$ as long as width at base. Ratio of length of mesosoma/length of gaster 0.7-0.9.

Male. Unknown.

Hosts. Reared from a gall-midge (Diptera: Cecidomyiidae) on Croton floribundus (Euphorbiaceae). The gall-midge belongs either to Clinodiplosis or Alycaulus, and probably represents an undescribed species. The similar species O. flavirufa is one of few Omphalespecies with a host record. It has been reared from Dialecta sp. (Lepidoptera: Gracillariidae) on Cordia alliodora (Boraginaceae), i.e. a very different host and host plant from $O$. japii.

\section{Distribution. Brazil.}

\section{Material examined.}

Holotype female from BRAZIL, São Paulo State (SP), Jundiaí, Serra

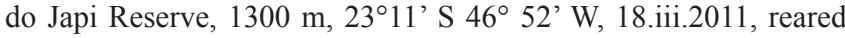
from galls on Croton floribundus, collected by Gabriela C. Gomes and Maíce S. Franco (deposited in MUNI). Paratypes: 9 females with same label data as holotype (BMNH, MUNI, MZSP); 6 females from same locality and same host as holotype but collected ii.2011 (MUNI, MZSP).

Etymology. Named after collecting locality.

Remarks. Omphale japii sp.nov. belongs to species-group scutellata, i.e. to same group as the similar O. flavirufa.

\section{Acknowledgements}

Thanks to Maria Virgínia Urso-Guimarães for the identification of the gall-maker, Jober Fernando Sobczak and João Vasconcellos-Neto for help with development of the work. Thanks also to the Department of Biology, Lund University, for the use of their SEM facility.

\section{References}

BOUČEK, Z. \& ASKEW, R.R. 1968. Index of Palaearctic Eulophidae (excl. Tetrastichinae). Le Francois, Paris, Index of Entomophagous Insects, v.3, 254p.

CORREA, M.P. 1984. Dicionário das plantas úteis do Brasil e das exóticas cultivadas. Imprensa Nacional, Rio de Janeiro, v.1, p.503-504.
DE SANTIS, L. 1979. Catálogo de los himenópteros calcidoideos de América al sur de los Estados Unidos. Publicacion Especial, La Plata, 488p.

DZIURZYNSKI, A. 1961. The inhabitants of the galls of Mikiola fagi Htg. Part I. Materials for the morphology and development of Mikiola fagi Htg. (Itoniidae), as well as of its endophagous primary parasite Secodes coactus Ratzb. (Chalcididae). Acta Zool. Cracov. 6:9-49.

FERNANDES, L.B.R., DIAS FILHO, M.M., FERNANDES, M.A. \& PENTEADO-DIAS, A.M. 2010. Ichneumonidae (Hymenoptera) parasitoids of Lepidoptera caterpillars feeding on Croton floribundus Spreng (Euphorbiaceae). Rev. Bras. Entomol. 54(2):263-269. http:// dx.doi.org/10.1590/S0085-56262010000200009

GIBSON, G.A.P. 1997. Morphology and terminology. In Annotated Keys to the Genera of Nearctic Chalcidoidea (Hymenoptera) (Huber, J.T., Woolley J.B.). NRC Research Press, Ottawa, 794p., p.16-44.

GRAHAM, M.W.R.V. 1959. Keys to the British genera and species of Elachertinae, Eulophinae and Euderinae (Hym., Chalcidoidea). Trans. Soc. Brit. Entomol. 13:169-204.

GRAHAM, M.W.R.V. 1963. Additions and corrections to the British list of Eulophidae (Hym., Chalcidoidea), with descriptions of some new species. Trans. Soc. Brit. Entomol. 15:167-275.

HANSON, P.E. \& GAULD, I.D. (eds.). 2006. Hymenoptera de la Región Neotropical. Mem. Am. Entomol. Inst. 77:1-994.

HANSSON, C. 1996. Taxonomic revision of the Nearctic species of Omphale Haliday (Hymenoptera: Eulophidae). Entomol. Scand. Suppl. 49:1-78.

HANSSON, C. 1997. Mexican species of the genus Omphale Haliday (Hymenoptera: Eulophidae), a taxonomic study. J. Hymenoptera Res. 6:107-151.

HANSSON, C. 2004. Eulophidae of Costa Rica, 2. Mem. Am. Entomol. Inst. 75:1-537.

LASALLE, J. \& SCHAUFF, M.E. 1992. Preliminary studies on Neotropical Eulophidae (Hymenoptera: Chalcidoidea): Ashmead, Cameron, Howard and Walker species. Contrib. Am. Entomol. Inst. 27:1-47.

MAIA, V.C. \& FERNANDES, G.W. 2004. Insect galls from Serra de São José (Tiradentes, MG, Brazil). Braz. J. Biol. 64(3):423-445. http://dx.doi. org/10.1590/S1519-69842004000300007

MEDINA, J.M., PEIXOTO, J.L.B., SILVA, A.A., HARAGUCHI, S.K., FALAVIGNA, D.L.M., ZAMUNER, M.L.M., SARRAGIOTTO, M.H \& VIDOTTI, G.J. 2009. Evaluation of the molluscicidal and Schistosoma mansoni cercariae activity of Croton floribundus extracts and kaurenoic acid. Rev. Bras. Farmacogn. 19(1B):207-211. http://dx.doi.org/10.1590/ S0102-695X2009000200005

NOYES, J.S. 1982. Collecting and preserving chalcid wasps (Hymenoptera: Chalcidoidea). J. Nat. Hist. 16:315-334. http://dx.doi. org/10.1080/00222938200770261

NOYES, J.S. 2012. Universal Chalcidoid Database. http://www.nhm.ac.uk/ research-curation/research/projects/chalcidoids/database/ (último acesso em 04/04/2012).

PRICE, P.W., BOUTON, C.E., GROSS, P., McPHERON, B.A., THOMPSON, J.N. \& WEIS, A.E. 1980. Interactions among three trophic levels: influence of plant on interactions between insect herbivores and natural enemies. Ann. Rev. Ecol. Syst. 11:41-65. http://dx.doi.org/10.1146/ annurev.es.11.110180.000353 